\title{
Cultural Diversity of Marriage Sustainability in Nigeria: Strengths and Challenges
}

\author{
Ime N. George*, David E. Ukpong, Eme E. Imah \\ Department of Educational Foundations, Guidance and Counselling,Faculty of Education, University of Uyo, \\ Uyo,P.M.B. 1017, Akwa Ibom State, Nigeria \\ *Corresponding Author: nsisong99@yahoo.com
}

Copyright (C) 2014 Horizon Research Publishing All rights reserved.

\begin{abstract}
This paper examines the marriage pattern across several cultures. In doing so, it analyses problems and prospects of the institution and also provides insights into several marital practices observed across cultures. It also examines forms of marriage, marital expectations and myths. Furthermore, it discusses the patterns of marriage, its changing institution and what makes marriage to work. These include establishing love maps, nurturing fondness and admiration, turning towards each other instead of away, making one's partner to influence the other, solving solvable conflicts, overcoming gridlock and creating shared meaning. It concludes by stating that not all marriages are illusional for the same reason, nor is there usually one reason for an unworkable marriage.
\end{abstract}

Keywords Marriage Patterns, Culture, Marriage Problems and Prospects

\section{Introduction}

The concept of marriage is a universal phenomenon which cuts across races of all ages and cultures in spite of the diversity of customs, forms, and functions. This diversity in the aspect of marriage makes it difficult to define marriage succinctly in a way that encompasses all forms of marriages. However, various Anthropologists have proposed several compelling definitions of marriage so as to accommodate the wide variety of marital practices observed across many cultures. In his book, the History of Human marriage, Westermarck (1968) defined marriage as "a more or less, durable connection between male and female lasting beyond the mere act of propagation". Furthermore, the Anthropological handbook, "Notes and Queries published in 1951, sees marriage as a union between a man and a woman such that children born to this woman are the recognized legitimate offspring of both partners.

Leach (1967), a British anthropologist criticized these definitions as being too restrictive in terms of recognized legitimate offspring, and suggested that marriage be viewed in terms of the different types of rights it serves to establish. Leach expanded the definition and proposed that "Marriage is a relationship established between a woman and one or more other persons, which provides that a child born to the woman under circumstances not prohibited by rules of the relationship is accorded full birth-status right common to normal members of his society or social stratum. Leach argued that no one definition of marriage applies to all cultures and therefore offered a list of rights associated with marriage, including sexual monopoly and rights with respect to children which of course differ across cultures. Similarly, Duran Bell (1960) criticized the legitimacy-based definition of Leach on the basis that some societies do not require marriage for legitimacy, arguing that in societies where legitimacy means only, that the mother is un-married and has no other legal implications, a legitimacy-based definition of marriage is secular. Bell rather proposed to define marriage in terms of sexual access rights.

Although, the institution of marriage pre-dates reliable recorded history, many cultures have legends concerning the origin of marriage. The way in which a particular marriage is conducted and its rules and ramifications has changed over time, as well as the institution itself, depending on the culture or demography of the time. According to Hanon and White (1997), various cultures have had their own theories on marriage and its origin, one example is a man's need for assurance concerning the paternity of his children. He might therefore be willing to pay a bride price, or provide for a woman in exchange for exclusive sexual access, therefore, legitimacy becomes the consequences of this transactions rather than its motivation. This idea agrees with Leach's definition of marriage in terms of full birth status rights to the offspring of the marriage, including the man (husband) having sexual monopoly and right on the woman (wife) concerned.

Various marriage practices have existed throughout the world. In some societies, an individual is limited to having one partner at a time (monogamy) while other cultures allow a male to have more than one wife (polygamy), or, less commonly, a female to have more than one husband (polyandry). Some societies allow marriage between two 
males, or two females. Others have certain restrictions on marriage based on the ages of the participants, pre-existing kinship, and membership in religious or other social groups.

\section{Methodology}

This study adopts utilizes the historical comparative approach. Many controversies have arisen over the centuries in relation to marriage as regards the sustainability of partners of different Nigerian cultures, religious faiths, tribe, rights of partners, acceptable number of children, and minimum age of husband or wife. Year after year all over the world, marriage has been discussed in public forums and private sessions with undiminished confusions and increasing pessimism. Failed marriages have been attributed to several compelling factors in many cultures around the world. Thus, the method used in this study is suitable because it allows the readers to see at a glance the factors responsible for failed marriages in different Nigerian cultures and how to guard against them.

\section{Selection of Marriage Partner in Some Cultures of the World}

Traits that people look for in their marriage partners vary around the world. In one large-scale study of 9,474 adults from 37 cultures on six continents and five Islands, people were found to vary on how much they valued chastity desiring a marital partner with no previous experience in sexual intercourse (Buss and others, 1990). Chastity was the most important factor in marital selection in China, India, Indonesia, Iran, Taiwan, and the Palestinian Arab culture. Adults from Ireland and Japan placed moderate importance on chastity. In contrast, adults in Sweden, Finland, Norway, the Netherlands, and Germany generally argued that chastity was not important in selecting a marital partner, the authors explained.

In the study, domesticity was also valued in some cultures and not in others. Adults from the Zulu culture in South Africa, Estonia, and Colombia place high premium on housekeeping skills in their marital preference. By contrast, adults in the United States, Canada, and all Western European countries except Spain, argued that housekeeping was not an important trait in their partner.

Sheriff-Trask (2003) opined that religion plays an important role in marital preferences in many cultures. For example, Islam stresses the honour of the male and the purity of the female. It also emphasizes the woman's role in childbearing, child rearing, educating children, and instilling the Islamic faith in their children.

Comparisons of marriages internationally also reveals that individuals in Scandinavian countries marry late, whereas their counterparts in Eastern Europe marry early, (Blanchi and Spani, 1986). In Denmark, for example, almost 80 per cent of the women and 90 per cent of the men aged 20 to 40 have never been married; while less than 40 per cent of the women and 70 per cent have never been married in Hungary.

Studies by Blanchi and Spani (1986) reveal that in Scandinavian countries co-habitation is popular among young adults, and that, most Scandinavians eventually marry only 5 per cent of the women they cohabitate and 11 per cent of the men in their early forties have never been married. The researches added that, some countries such as Hungary encourage early marriage and childbearing to offset current and future population losses. In the same way, Japan has a high proportion of unmarried young people. However, rather than co-habiting women as Scandinavians do, unmarried Japanese young adults lie at home longer with their parents before marrying.

\subsection{African experience}

Marriage in Africa is seen as sacred, because it solidifies relationships that enrich communities and nations by bringing forth new life and new hope. Although Africa is large and varied in cultures as a continent containing some of the oldest civilizations on earth, it is a home to a wide diversity of religion and cultures. This colourful diversity is reflected in its colourful wedding ceremonies (Westermarck, 1968).

Westermarck asserted that marriage has brought political stability in the growth of every major empire, and is even used to broker unity between belligerents in Europe, Africa and Asia. Also, marriage between clans and nations has been a way of securing peace and promoting trade. Commenting on pan-Africanism, he added that marriage and pan-Africanism are interlinked because it is the most central and common African tradition, sacred to all African people on the continent, therefore, serving as the building block of nationhood and the first form of unity. Suffice it to say that, in almost all societies according to studies, access to women is institutionalized in some way so as to regulate the intensity of this competition.

\subsection{Ancient Israel}

In Ancient Israel, a wife was seen as being of high value and was therefore, usually, carefully looked after. The early nomadic communities practiced a form of marriage known as beena, in which a wife would own a tent of her own, within which she retains complete independence from her husband. This practice appeared to survive in parts of early Israeli societies as some early passages of the Bible portray certain wives as each owning a tent as a personal possession (see Judges 4:7, Gen. 24:26, and Gen. 31:33-34).

In later times, the Bible describes wives as being given the inner room(s) of the husband's house, as her own private area to which men were not permitted. This is seen in Judges 15:1 and 16:9 respectively, especially in the cases of wealthy husbands.

Suffice it to say that it was not a life of total freedom, because the descriptions of the Bible suggest that, a wife was 
expected to perform certain household tasks, such as; spinning, sewing, wearing, manufacture clothing, fetching of water, baking of bread, and animal husbandry. According to the covenant code, the husband too is indirectly implied, to have some responsibilities to his wife/wives. These include the provision of food, protection, sexual activity and, should these fail, she was to divorce him without cost. The Talmud interprets this as a requirement for a man to provide clothing to, and have sex with each of his wives, even if he only has one. Studies also show that Israel being a polygamous society did not have laws which imposed marital fidelity on men.

Adulterous married women and adulterous betrothed women however were subjected to the death penalty by the Jewish laws against adultery, as well as their male accomplices. The literally prophets indicate the adultery was a frequent occurrence, despite their strong protest against it and these legal strictness.

\subsection{Europe}

Records have it that marriage in Ancient Greece required no specific civil ceremony for its creation - only mutual agreement, and the fact that the couple must regard each other as husband and wife accordingly. Men usually married in the 20's and women in the teens. Suggestions are that these ages made sense for the Greeks because men were generally done with military service or financially established by their late 20's. Married Greek women had few rights and the ancient Greek society was expected to take care of the house and children.

Time was an important factor in Greek marriage. For example, there were superstitions that being married during a full moon was good luck, and according to Flaceliere (2000) Greeks often times married in the winter. Inheritance was also more important than feelings, for example, a woman whose father died without male heirs could be forced to marry her nearest male relative even if she had to divorce her husband first.

Excerpts retrieved from Hirschfield's archive, 2010 revealed that the Roman Empire had several types of marriages in ancient Roman society. It is stated that the traditional marriage ("conventional") form called "conventio" in manum required a ceremony with witnesses and was also dissolved with a ceremony. Women lost their family rights of inheritance of their old families (maiden family), and gained them with their new one in this type of marriage and also surrendered to the authority of the husband. On the other hand another kind of marriage called free marriage was also practised. It was known as sine-manu and involved an arrangement, which the wife will remained a member of her original family while still staying under the authority of the father, kept her family rights of inheritance with her old family and did not gain any within the new family. Girls' minimum age for this marriage was 12 years.

For many centuries, marriage has metamorphosed from one stage to the other through the influence of protestant, reformation and counter reformations but in the early part of this century, John Calvin and his protestant colleagues reformulated Christian marriage by enacting the marriage ordinance of Geneva which imposed and dual requirements of stage registration and church consecration to constitute marriage for recognition, (Witte Jr. 1997). For example in England and Wales, Lord Hardwicke's marriage Act of 1753 required a formal ceremony of marriage, thereby curtailing the practice of fleet marriage (Leah, 1999).

According to the author, clandestine or irregular marriages were performed at fleet prison, and at hundreds of other places between 1690's until the marriage Act of 1753 numbered 300,000 thus the Act required a marriage ceremony to be officiated by an Anglican priest in the Anglican Church with two witnesses and registration. Church marriages came to be recognized as a legal alternative to court marriages under the Marriage Act of 1836.

\subsection{China}

In Ancient Chinese society, people of the same surname were supposed to consult with their family trees prior to marriage to reduce the potential risk of unintentional incest (Kueffler, 2007). So marrying to one's maternal relatives was generally not thought of as incest, families, sometimes intermarried from one generation to another. But over time, Chinese people became more geographically mobile, hence a new marriage law of 1950 radically changed Chinese marriage traditions, enforcing monogamy, equality of men and women, and choice in marriage, arranged marriages were the most common type of marriage until then.

\subsection{Nigeria}

In Nigeria, marriage is regarded as one of the most important social customs which gives an individual respect and status, thereby putting pressure on many single people to marry. Besides, marriage is also viewed as a way of making one big family out of two families, hence the pressure on the bride and bridegroom to make the marriage work, as any problem will usually "affect both families and strain the otherwise cordial relationship between them.

Amiru (2010) identified three (3) types of marriages practised in Nigeria to include; Traditional marriage or (Native law and custom), Religions (Church, etc) and Civil (Court) marriage.

A Nigerian couple can decide to take part in one or all of them and the number usually boils down to culture and wealth. Amiru explained that however, two major forms of marriages exist in Nigeria; monogamy - a marriage of one man to one woman, and polygamy - a marriage of one man to two or more wives. This practice cuts across almost all the tribes in Nigeria.

Opponents of polygamy argued that, it is a descriptive force to the family, putting wives against each other while supporters argued that it can be a unifying factor by allowing 
wives to work together. However, this not-withstanding; marriage is still very much valued in the Nigerian society and its worthy of note that traditional marriage in Nigeria is usually an arrangement between two families as opposed to an arrangement between two individuals in most Western culture. The cultural diversity, richness and distinctive qualities of Nigerian society are reflected in the various family types within the country.

\section{Forms of Marriages in Some Cultures}

Various cultures across the globe have various traditions and rituals associated with the solemn ritual of marriage. The western world and the eastern world vary a lot in these rituals and traditions. They also in their take on marriage, as there are more than one type of marriage. Different marriages are approached in different ways, some prefer one type of marriage whereas others prefer the other.

Below are the various forms or types of marriages with some categories commonly co-existing in the same marriage as researched by Libertive, 2008.

Polyandry: This form of marriage is much less common, this is when one woman has several husbands. It has occurred in Tibet, Mongolia, the Canadian Arctic, South America, Nepal, Blutan, among other places. Polyandry is especially suited to populations that have more males than females which is perhaps the reason why it is less common than polygamy, because females outnumber males in most societies. Apparently, because of the couple's restriction to one child only, combined with the traditional Chinese preference for male children, it has created an unnaturally lopsided sex ratio of males to females. Polyandry could therefore be a useful strategy in China in the future to rebalance the sex ratio.

Polyamory: This is a type of marriage restricted to a specific group of people that only members agree to marry among themselves. For example, members of one Christian denomination marrying only among themselves. It could be viewed as "expanded monogamy".

Same Sex Marriage: This is a form of marriage between two persons of the same biological sex or gender identity. Supporters of legal recognition for same sex marriage typically refer to such recognition as marriage equality. Recent records have it that since 2001, about ten countries have begun to allow same-sex couple to marry. These countries include; Argentina, Belgium, Canada, Iceland, the Netherlands, Norway, Portugal, Spain, South Africa and Sweden. Others are Brazilian states of Alagoas, Mexico City and parts of the United States.

In Nigeria, the proposed ban on same-sex partnerships indicates that Nigeria recognizes neither same sex marriages nor civil unions for same-sex couples. A bill passed on 29th November, 2011 into law in Nigeria pronounces 5 years imprisonment for anyone who undergoes, "performs, witnesses, aids, or abets" a same-sex marriage. It also prohibits any display of "same-sex" amorous relationship and adoption of children by gays or lesbians. This bill makes Nigeria the second country in Africa to criminalize such union. Uganda had earlier banned same sex marriage in 2005.

Open Marriage or Swinging:Open marriage occurs when couples in legal, monogamous marriages both agree that each may have outside lovers. Each spouse has their own lovers, whom they may or may not also have sexual dealings with.

\section{The mirage about Marriages}

Mirage may be defined as a natural optical phenomenon in which light rays are bent to produce displaced image of distant object. It is scientific in nature and is caused by cold air having a greater refractive index as light passes from colder air across sharp boundaries to significantly warmer air.

From the above definition, one thing is salient about the word "mirage', and that is "illusion". Illusion is something unattainable or giving a false impression or idea or belief about something. Many controversies have arisen over the centuries in relation to marriage including issues relating to the sustainability of partners of different denominations, faiths, tribes or races, the acceptable number, and minimum age of wives, the rights of partners, especially wives and wider family obligations.

Year after year, all over the globe, marriage has been discussed in public fora and private sessions with undiminished confusion and increasing pessimism. According to a study by Ramat (2000), in Mumbal-India, facts revealed is about failed marriages were attributed to the growing importance of careers and inducement of India into the Global economy combined with huge exodus of India migrants to western countries.

The researcher explained that, marriage has suddenly become such an enigma that the brunt of deprecating humour has in this generation been regarded as a burden and not a necessarily. Kamat opined that family ties have weakened, traits such as togetherness, tolerance and adaptability are being replaced by individualism. Similarly, recent surveys in the United States of America indicate that in an affluent community like San Mateo, California, seven out of ten marriages have failed, and one third of all marriages end in divorce within ten years even as the remaining two thirds are very calamitous.

Another researcher, Meninger (2000) opined that, the current mirage about marriage in the USA bothers on the customs and basis which dominates attitudes towards marriage which grew out of conditions appropriate to the past, not the present. As he puts it, this influence of the past, is most easily apparent in the legal aspects of marriage. Hence, current laws concerning marriage, divorce, alimony and custody were taken enmasse from English common law, some of which are more than 500 years old. Meninger further explained that these laws have been altered minimally and 
have not been adapted to meet the demands of the twentieth-century America, therefore, making the current concepts of marriage anchored on social, legal and psychological anachronisms that result in un-workable marriages.

In the contemporary society, for an example Nigeria, on a typical wedding day, a young man and a young woman standing before the priest, minister or justice of the peace, usually have a high opinion of one another. They are overflown with joyous thoughts, each having a firm assurance of the other's marital bliss.

Many social commentators in western societies have expressed concerned about what they see as the decline standard marriage. Many see this as a threat to family, which in turn is the bedrock of the stable and civilized society. A number of threats to marriage he been identified. Hartson (1983) argued from functionalist perspective that the adaptation of the family to the requirements of economic system has placed a strain on the marital relationship. He explained that, it has led to the relative isolation of the nuclear family from the wider kinship network. Hart asserted that, as a result of the economic strain the family carries a heavier emotional burden which exists independently than when it is a small unit within a larger kin fabric. Leach (1967), agrees that nuclear family suffers from an emotional overload, which increases the level of conflict between its members.

Gibson (1994) combines element of previous arguments by asserting that the development of modernity has increased the likelihood of conflict between spouses. He explained further that the way modernity has developed, puts increasing emphasis upon the desirability of individual achievement. Gibson (2006) on his part argued that people now lie in an enterprise and free market culture of individualism in which the licence of choice dominates. For him, a higher divorce rate may be indicative of modern couples generally anticipating a superior standard of personal marital satisfaction than was expected by their grandparents.

Lederer et al (1968), opined that couples no longer build enduring human relationships depending on their interplay of behaviour which signals to each spouse that whatever he received has been forth coming in response to something given. In other words, a quid-pro-quo (something for something) agreement is in effect, to live in reasonable harmony, the spouses negotiate with respect in their behaviour and responsibilities. Perhaps this argument may appear selfish and unromantic, yet, it is viewed as the single most required but most overlooked aspect of any marriage. It is observed that most overlooked aspects of marriages end in mirage.

Lederer has asserted that most couples in the western world enter into marriage believing that "love" and romance in addition to plenty of gadgets will keep them happy. This grinning false-face concept of what marriage life will look like, forms the delusion that result in mirage marriages. From the fore-going explanation, it is obvious that marriages that lack solid background in values and needs of the husband and the wife are likely to end in mirage, thus, resulting in failed marriages.

In another development, recent survey in the United State of America on failed marriages show that there are about 400,000 divorces annually, yet, these statistics do not reveal the entire marital tragedy. More often than not spouses admit that marriages traverse years of dislike and mutual distrust rather than love and mutual growth. Leach confirms this by stating that interviews with hundreds of average marital pairs in the USA reveal that approximately $80 \%$ of the couples had seriously considered divorce at one time or the other, while many of them still think about it frequently. He explained further that often, it is only the existence children, restriction of poverty, edicts of religion, or a lack of courage that discourage the decision to divorce. It appears that since the American marriage institution is ailing, there is need to consider what can be done about the mirage in marriage in order to salvage it. There is the need for couples to build enduring relationships depending on interplay of behaviour which signals to each other that whatever is received has been forthcoming in response to something given.

It is to be noted that the rise rate of divorce cases or failing marriages is not just a U.S. phenomenon. The divorce rate has accelerated over the last several decades in most industrialized countries expect Japan and Italy (Cherlin, 1993, Ahron, 1995). Changes in matrimonial and divorce trends have led to a doubling in the number of single-parent households in the United State over the past two decades. More than one quarter of the family household are now headed by single parent, compared with 13 per cent in 1970 , and half of all black children and almost one-third of Hispanic children live in homes with only one parent. Furthermore, it should be noted that in most single-parent families, the children reside with the mother, not the father a phenomenon that is consistent across racial and ethnic groups throughout industrialized world (Burns and Scott, 1994; U.S. Bureau of the Census, 1997).

The resulting consequences of most failed or divorced marriages are that, these single-parents families, are often economically less well off, diminishing children's opportunities and the inability to adequately care for them. Time is always at a premium in single-parent families (Hetherington, 1999; Wallestein, Lewis and Blakeslee, 2000). Moreover, for children of divorce, the parents' separation is often a painful experience that can make it difficult, for the children to establish close relationship later in life. However, the consequences for children living in single-parent household are not invariably negative or positive. Certainly, the large number of single-parent households has largely reduced the stigma of such family situations in that, however children fare, then depends on a variety of factors, including the family's economic status, the amount of time the parent can devote to the children and overall amount of household stress. 


\section{Working-Class Women-a Threat to the Institution of Marriage}

Doyle (1999), Smock (2000) and Bachracl (2000) asserted that the evidence that marriage is a societal institution that is undergoing significant change are based on the premises.

Women's "Second shift". The number of hours put in by working mothers can be staggering on survey. It is found that working mothers of children under 3 years of age worked on average of ninety hours per week. Sociologist Arlie Hochschild refers to the additional work experienced by women as the 'second shift'. According to her analysis of national statistics, employed mothers put in an extra month of 24 hours day during the course of a year. Similar patterns are seen in many developing societies throughout the world, with women working at full time jobs and also having primary responsibilities for child care (Hochschild, 1990; Hochschild, Machung, and Pringle, 1995, Mednick, 1993).

Rather than women's career being a substitute for household work, they are usually an addition to the role of homemaker. It is not surprising that some wives feel resentment toward husbands, who spend less time on child care and house-work than the wives had expected before the birth of their children (Williams and Mc cullers, 1983, Ruble et al., 1988; Crouter et al., 1999; Stier and Lewin-Epstein, 2000). The authors explained that the value of work, has gone beyond merely earning a salary since it provides personal satisfaction as well as sense of contributing to society. It is so valuable because it provides an escape route from the rigors of a frenetic, stress-filled home life.

One of major reason for mirage in marriage is living a devitalized marriage life. George (2009) explained that after a space of time specifically when couples start bearing children, the once intimate relationship starts dwindling and little or no time is devoted for each other as before. Far less satisfying qualitatively and quantitatively with the result that relationship with each other becomes more and more mechanical and less thrilling; with interest and activities formerly engaged together no longer shared, if shared at all not in a deeper sense of it. Therefore, constraining the union which if not attended promptly to, could lead to ailing relationship and subsequently divorce.

George further explained that marriage where spouses are seen to be quarrelling, nagging and fighting each other very often would definitely or is already ailing and may end in divorce. This is so because, rancour and conflict invested atmosphere are not usually safe for expressing genuine love and affection towards one another.

On the whole, whatever may be the cause for ailing marriages, or making marriages to becoming a mirage, couples should learn to build intimate relationships, there should be high sense of commitment, respect, transparency, forgiveness, forbearing, sensitivity, open communication, and lots more. Whenever any conflict arises, couple should always strive to resolve it and not diffuse amongst themselves and except absolutely necessary, should the opinion of third party be sought.

\section{Factors that can Make Marriage Work Well in Nigeria}

Gottman (1994); Gottman and Notarius (2000); Gottman and Silver (1999); Gottman and others (1998) have been studying married couples' lives since the early 1970s, with a view to discovering what makes marriage to work.

Gottman interviews couples about the history of their marriage, their philosophy concerning marriage, and how they view their parents' marriages. He also uses physiologic indices to measure their heart rate, blood flow, blood pressure and immune functioning moment. He checks back with the couples every year to see how their marriage is fairing. This research represents the most extensive assessment of marital relationship available. Currently, his colleagues are following about 700 couples in seven different studies. In his research, Gottman has found that these seven main principles determine whether a marriage will work or not:

Establishing love maps: Individuals in successful marriages have personal insights and detailed maps of each other's life and world. They aren't psychological strangers. In good marriages, partners are willing to share their feelings with each other. They use these 'love maps' to express not only their understanding of each other, but also their fondness and admiration.

Nurturing fondness and admiration: In successful marriages, partners sing each other's praises. More than 90 per cent of the time, when couples put a positive spin on their marriage's history, the marriage is likely to have a possible future.

Turning toward each other instead of away: In most stable marriages, Gottman discovered that spouses are adept at turning toward each other regularly. They see each other as friends and this friendship acts as a powerful shield against conflict. The friendship doesn't keep arguments from occurring, but it can prevent differences of opinion from overwhelming a relationship. In these marriages, spouses respect each other and appreciate each other's point of view en though they might not agree with it.

Allowing partners to influence each other: Gottman explained that bad marriages often involve one spouse who is unwilling to share power with the other. Although power-mongering is more common in husbands, some wives also show this problem. A willingness to share power and to respect the other person's view is a prerequisite to compromising.

Solving solvable conflicts: Gottman found two types of problems that occur in marriage: Perpetual and Solvable. Perpetual problems include spouses differing on whether to have children and one spouse wanting sex far more frequently than the other. Solvable problems include not helping each other reduce daily stresses and not being verbally affectionate. Unfortunately, more than two thirds of marital problems fall into this category.

Overcoming Gridlock: In this case, one partner wants the other to attend church, while the other remains an atheist. 
One partner is homebound; the other goes out and socializes a lot. Such problems often produce gridlock. Gottman believes the key to ending gridlock is not to solve the problem, but to move from gridlock to dialogue and be patient.

Creating shared meaning: The more partners can speak candidly and respectfully with each other, the more likely it is that they will create shared meaning in their marriage. This also includes sharing goals with one's spouse and working together to achieve each other's goals.

\section{Summary and Conclusions}

High divorce rate and marital dissatisfaction in many marriages are occasioned by the fact that couples expect their spouses to be their lover, friend, confident, counsellor, career person, and parent all at the same time. In a study, unhappy married couples were found to have expressed unrealistic expectations about their marriage (Epstein \& Eidelson, 1981).

Marriage therapists believe that it is important to have realistic expectations (Sharp and Ganong, 2000). On the same token researchers have found that unrealistic expectations are associated with lower levels of marital satisfaction (Larson and Holman, 1994). Therefore, individuals who have highly romantic beliefs about marriage are likely to encounter disappointment as they realize that sustaining their romantic aspirations is not possible (Huston, Neihuis, and Smith, 1997).

A survey in Nigeria by Adamu (2010) revealed that marriages are becoming enigmatic. Statistics from his survey show that about 60 per cent of marriages contracted within a year in Nigeria fail or are at the brink of failure before the first anniversary. The un-official failing or ailing marriages may probably be worse because they are off record. He attributed this problem to numerous reasons which include greed, false life style, negative parental influence and negative foreign tradition inculcated into the youth by the media. Others are spousal abuse, lack of communication, non-commitment to marriage responsibilities infidelity and poverty. Adamu opined that parents should desist from inculcating materialistic values in their children. They should assess their children suitors by morality and uprightness rather than their material worth. Government should come up with corrective measures that will check excesses during marriage ceremonies, while traditional rulers as the overall custodians of our cultural values should provide some strategies to effectively combat the menace on the society at large, through its basic institutions.

\section{REFERENCES}

[1] RAdamu, A. (2010). Failed, marriage on the rise in Nigeria. The Journal of Marriage and Family, Vol. (iii), p. 6-10.
[2] American Psychological Association (2010). "Resolution on sexual orientation and marriage". New York, Irrington.

[3] American Academy of Matrimonial Lawyers; "Making marriage work". Dubuque IA, Brown.

[4] Ahrons, C. (1995). The Good Divorce Keeping your family ... when your Marriage comes Apart. Journal of Marriage, Vol. 4, pp.20-26.

[5] Blanken, H. D. (2008). Protecting marriage to protect children. Cambridge, MA: Havare University Press.

[6] Buss, D. M., \& others (1990). International preferences in selecting mates: A study of 37 cultures. Journal of Cross Cultural Psychology, 21-27.

[7] Blanchi, S.M., \& Spani, D. (1986). American women in transition. New York: Russell Sage Foundation.

[8] Esptein, N., \& Eidelson, R. J. (1981). Unrealistic beliefs of clinical couples: Their relationship to expectations, goals and satisfaction. American Journal of Family Therapy, 9, 12-13.

[9] Flagagan, C., Faison, N. (2000). Youth civic development: implications of research for social policy and programs, Social Poly Report XV (No. 1), 1-14.

[10] Gottman, J. M., \&Levenson, R. W. (2000). The timing of divorce: Predicting when a couple will divorce over a 14 year period. Journal of Marriage and Family, 62, 645-737.

[11] Gottman, J. M., \&Declaire, J. (1997). The heart of parenting, raising and emotionally intelligent child. New York: Simon and Schuster.

[12] Gottman, J. M., \& Silver, N. (1999). The seven principles for making marriages work. New York: Crown.

[13] Gottman, J. M., \& Parker, J. G. (Eds.) (1987). Conversations of friends. New York: Cambridge University Press.

[14] Gottman, J. M. (1994). Why marriages succeed or fail. New York: Simon and Schuster.

[15] Gottman, J. M. \& Notarius, C. I. (2000). Decade review observing marital interaction. Journal of Marriage and Family, 62, 927-947.

[16] George, I. N. (2009). Family, sex and marital counselling. Uyo: Abaam Publishing Co.

[17] Gibson, I., Ritzer, G. (2000). Sociological theory. McGraw-Hill, International Edition.

[18] Gallagher, M. (2002). "What is marriage for? "The public purpose of marriage law". Louisiana Law Review.

[19] Huston, T. L., Neihuis, S., \& Smith, S. (1997). Divergent experiential and behavioural pathways leading to marital distress and divorce. Paper presented at the meeting of the National Council on Family Relations, Washington, D.C.

[20] Hammann, C. A. and White, S. (2008). Psychological Effects and Management of Parental Loss. American Journal of Obstetrics and gynaecology, 14, 46-50.

[21] Hartsock, N. (1983). Money, sex and power: Towards a feminist historical materialism. New York: Longman.

[22] Hetherington, E. M. (1999); Wallestein, Lewis and Blakeslee (2000). Coping with divorce, single parenting and remarriage: A risk and resiliency perspective. Mahwah, NJ: Eribaum. 
[23] http://www.scrib.com./doc/748072 03/Nigeria same-sex-marriage - Bill - Final.

[24] http://Nigerian womenworld.com/highlights/traditional-marr iages in Nigeria.html.

[25] http://www.aaml.org/marriage and last/marriage last.

[26] Jewish Encyclopeida (1901-1906) Article on 'Marriage'.

[27] Kueffler, H., Mathew, I. (2007). "The marriage revolution in late antiquity", "The Theodocian Code and Roman marriage law". Journal of Family History, Vol. 32, pp. 343-370.

[28] Larson, J. H. and Holman, T. B. (1994). Premarital predictors of marital quality and stability. Family Relations, 43, 228-237.

[29] Leach, E. (1967). The problematic relationship. New York: Vintage.

[30] Lederer, W. I. and Jackson, D. O. (1968). "The mirage of marriage". New York, London: W. W. Norton.
[31] Gordon, S. (2005). Marriage: A History, Psychology Today. New York, Willey.

[32] Marriage of same-sex couples (2006). Position statement: Canadian Psychological Association, October 30, 2011.

[33] Roman Empire: Magnus Hirsch Field Archive of Sexology" Hu-berlin de August 27, 2010.

[34] Sharp, E. A., and Gangong, L. H. (2000). Awareness about expectations: Are unrealistic beliefs changed by integrative teaching? Family Relations, 49, 71-76.

[35] Sheriff-Trask, B. (2003). Love courtship and marriage from a cross cultural perspective. In R.R. Hamon and B. B. Ingolds by (Eds.), Mate selection across cultures. Thousand Oaks CA: Sage.

[36] Witte, Jr. J. (1997). From sacrament to contract marriage, religion and law in the western tradition. England: West Minister John Knox Press, pp. 39-40.

[37] Westermarck, E. (1968). A short history of marriage. England: Humanities Press. 